\title{
Character Strengths and Life Satisfaction of Slovenian In-service and Pre-service Teachers
}

POLONA GRADIŠEK ${ }^{1}$

$\approx$ Character strengths and life satisfaction of Slovenian in-service and preservice teachers were researched. The VIA-IS self-assessment questionnaire has been translated into the Slovenian language and has been used for the first time in Slovenia. A total of 173 primary school teachers and 77 student teachers from the Faculty of Education, University of Ljubljana, completed the VIA-IS and the Satisfaction with Life Scale questionnaires. The highest reported strengths in both groups studied were fairness, kindness, integrity and love. Unexpectedly, both in-service and pre-service teachers reported low endorsements of creativity; inservice teachers also showed low endorsement of humour. Surprisingly, the lowest endorsed strength of pre-service teachers was love of learning. Correlations between strengths and life satisfaction were consistent with related research findings. Low endorsement of creativity, teachers' humour and students' love of learning are discussed. From the research findings, it can be concluded that professional environment should stimulate, as well as provide support and opportunities for teachers to build not only upon the strengths of humanity and justice, but also on those of wisdom and knowledge. There is a need in the undergraduate level of teacher education for systematic interventions regarding students' intellectual strengths with a special focus on cultivating their creativity.

Keywords: character strengths, life satisfaction, in-service teachers, pre-service teachers, positive psychology

1 Faculty of Education, University of Ljubljana, Slovenia polona.gradisek@pef.uni-lj.si 


\section{Vrline in osebnostne moči učiteljev in bodočih učiteljev ter zadovoljstvo z življenjem}

POLONA GRADIŠEK

$\propto V$ raziskavi smo proučevali vrline in osebnostne moči učiteljev in bodočih učiteljev ter njihovo zadovoljstvo z življenjem. Vprašalnik vrlin in osebnostnih moči VIA-IS je bil preveden iz angleškega jezika in prvič uporabljen v okviru te študije. V raziskavi je sodelovalo 173 osnovnošolskih učiteljev in 77 bodočih učiteljev, študentov Pedagoške fakultete Univerze v Ljubljani. Udeleženci so izpolnili vprašalnik VIA-IS in vprašalnik zadovoljstva $\mathrm{z}$ življenjem. V obeh skupinah udeležencev so bile najvišje izražene osebnostne moči poštenost, prijaznost, pristnost in ljubezen. Učitelji in bodoči učitelji so dosegli presenetljivo nizek rezultat na lestvici 'ustvarjalnost', bodoči učitelji pa tudi presenetljivo nizek rezultat na lestvici 'ljubezen do učenja'. Dobljene korelacije med osebnostnimi močmi in zadovoljstvom z življenjem so skladne $\mathrm{z}$ rezultati preteklih raziskav. V interpretaciji se osredinjamo na nizke rezultate na lestvicah 'ustvarjalnost' (v obeh skupinah udeležencev), 'ljubezen do učenja' (pri bodočih učiteljih) in 'humor' (pri učiteljih). Glede na dobljene rezultate ugotavljamo, da bi bilo treba učitelje in bodoče učitelje spodbujati, da bi gradili na vrlinah človečnosti, pravičnosti, modrosti in znanja, ter hkrati omogočiti učno in profesionalno okolje, v katerem bi bilo to mogoče. Rezultati kažejo na potrebo po sistematičnem spodbujanju intelektualnih vrlin na dodiplomski ravni izobraževanja bodočih učiteljev, s posebnim poudarkom na spodbujanju ustvarjalnosti.

Ključne besede: vrline, osebnostne moči, učitelji, bodoči učitelji, študentje, zadovoljstvo z življenjem, pozitivna psihologija 


\section{Introduction}

Psychology has traditionally focused on psychological deficits and disorders. However, since 2000, the emerging science of positive psychology aims to complement deficit-based approaches by focusing on aspects that make life most worth living (Seligman \& Csikszentmihalyi, 2000). The three main topics of positive psychology are: positive emotions (e.g. happiness, optimism), positive traits (e.g. character strengths), and positive institutions (e.g. schools, families) (Peterson \& Seligman, 2004; Seligman, Steen, Park, \& Peterson, 2005). As opposed to the humanistic psychology movement in the 196os, positive psychology investigates factors that enable human flourishing by using sound scientific research methods (Peterson \& Seligman, 2004).

During the previous decade, there was a growing interest in studying good character. Good character is essential for individuals and societies to thrive (Park, Peterson, \& Seligman, 2006). A major early initiative of the positive psychology movement was to develop a classification of character strengths and virtues. A classification of positive traits of character could provide a common language for understanding of what is good in people, as a parallel framework to the Diagnostic and Statistical Manual of Mental Disorders (DSM) or International Classification of Diseases (ICD), which provide a common language to discuss mental disorders. In order to develop a classification of positive individual traits, or character strengths, an extensive project was started: researchers examined widely influential religious and philosophical traditions; they also reviewed goals of positive education programs, virtue-relevant messages of greeting cards, bumper stickers, song lyrics, Tarot cards, cartoon characters etc. (Peterson \& Seligman, 2004). Dozens of candidate strengths to be included in the classification were identified. They were then assessed against 10 criteria proposed by Peterson and Seligman (2004) that a positive trait has to satisfy in order to be recognized as strength of character. Finally, a classification of 24 ubiquitously-recognized character strengths, organized under six core virtues was developed (Peterson \& Seligman, 2004):

1. wisdom and knowledge (creativity, curiosity, love for learning, critical thinking, perspective),

2. courage (bravery, honesty, perseverance, zest),

3. humanity (kindness, love, social intelligence),

4. justice (fairness, leadership, teamwork),

5. temperance (forgiveness, modesty, prudence, self-regulation),

6. transcendence (appreciation of beauty and excellence, gratitude, hope, humour, spirituality). 
Peterson and Seligman (2004) did not claim this classification to be final; the entries could change over time according to new research findings. The authors defined character strengths as the processes and mechanisms that lead to the virtues; thus, for example, the virtue of humanity can be achieved through love, kindness and social intelligence. Strengths were assigned to virtue categories on theoretical and not empirical grounds. Studies examining the factor structure of the classification usually report 4- or 5-factor solutions (Brdar \& Kashdan, 2010; Peterson \& Seligman, 2004; Ruch et al., 2010).

In order to measure character strengths, a 240-item self-assessment questionnaire, the Values in Action Inventory of Strengths, (VIA-IS; Peterson, Park, \& Seligman, 2004) was developed. It shows good psychometric properties (Park, Peterson, \& Seligman, 2006) and has been widely used in research. Due to its being a web-based technology and the popularity of this instrument in research and clinical work, more than one million people have completed the VIA-IS thus far (Brdar \& Kashdan, 2010; Park, Peterson, \& Seligman, 2004; Peterson, Ruch, Beermann, Park, \& Seligman, 2007).

Park, Peterson, and Seligman (2006) collected a vast sample of participants from fifty-four nations and all fifty US states, and investigated the relative prevalence of character strengths. The most commonly endorsed strengths were kindness, fairness, honesty, gratitude, and judgement; the less frequently endorsed strengths were prudence, modesty, and self-regulation. An important finding was that there was a similar ranking of strengths in all the countries studied. In a large UK sample (Linley et al., 2007), the rank ordering of strengths was largely consistent with findings across different nations (in this sample, the highest endorsed strengths were open-mindedness, fairness, curiosity, and love of learning; these were the same for men and women). However, women typically scored higher than men on almost all strengths, with the exception of creativity (Linley et al., 2007). The strongest effect sizes for gender differences were shown for kindness and love, where women scored higher. Linley et al. concluded that gender differences should not be overstated because there are more similarities than differences between genders. There were positive associations between strengths and age, with strongest effects showing for curiosity and love of learning, fairness, forgiveness, and self-regulation. Small but consistent effects could suggest a trend for character development (Linley et al., 2007).

Park, Peterson, and Seligman (2004) examined the relationships between character strengths and subjective well-being (SWB) by focusing specifically on life satisfaction as a cognitive component of SWB. Strengths should, by definition, contribute to fulfilment (Peterson \& Seligman, 2004); however, it 
has been found that certain strengths show stronger associations with life satisfaction: hope, zest, gratitude, love, and curiosity showed consistent and robust associations with life satisfaction, even when controlling for potential influence of age, gender, and US citizenship (Park, Peterson, \& Seligman, 2004; Ruch et al., 2010). There were only weak associations with intellectual strengths, appreciation of beauty, excellence, and modesty. These findings were replicated by Peterson et al. (2007); however, gratitude was amongst strongest predictors of life satisfaction in the US sample, whereas perseverance was a strong predictor in the Swiss sample. An important finding by Park, Peterson, and Seligman (2004) was that higher endorsement of a specific strength was reflected in higher life satisfaction reported.

Gratitude, hope, zest, curiosity and love are robustly associated with work satisfaction across different occupations (Peterson \& Park, 2006). The strengths of humanity could contribute to work satisfaction in professions that involve other people, like teaching (Peterson \& Park, 2006). There is only limited existing research on the character strengths of teachers. In a Chinese study (Chan, 2009), teachers reported higher levels of humanity and transcendence strengths compared to the general population, and showed higher levels of some specific strengths: love, gratitude, teamwork, spirituality, and hope. In this study, teachers completed The Strengths Inventory (Chan, 2009), which was developed to assess the 24 strengths for the purpose of that study. Peterson and Park (2006) found an association between the social and emotional intelligence of teachers and performance gains over the academic year on the part of their students.

Investigations into the character strengths of teachers and strengthsbased interventions have implications for teachers' development in teacher education (Chan, 2009). If teachers and future teachers identify and use their strengths, they can help students with identifying their strengths and talents. Moreover, teachers who are satisfied with their lives should be more able to help students in their personal development, as well as lead satisfying lives. In a sample of Chinese teachers (Chan, 2009), the strengths of zest, hope, gratitude, and humanity were robustly associated with subjective well-being, which is congruent with the findings of Park, Peterson, and Seligman (2004) cited above.

To date, no study has been conducted comparing character strengths of in-service and pre-service teachers using a complete VIA Inventory of Strengths. Therefore, we investigated the rank order of teachers' character strengths and compared the endorsement of strengths of in-service teachers and student teachers. Additionally, associations between strengths and life satisfaction in this specific sample were explored. 


\section{Method}

\section{Participants}

A total of 173 elementary school teachers (150 women and 23 men) and 77 students of the Faculty of Education of the University of Ljubljana (future science teachers, 68 women and 9 men) participated in the study. The prevalence of women in both samples reflects the typical gender ratio in the teaching profession in Slovenia. The mean age of teachers was 42.32 years $(S D=10.00$; range 24-62 years) and of student teachers 22.47 years $(S D=2.01$; range 20-29 years). Teachers from our sample teach different subjects in Grades 5 to 9 of Slovenia's nine-year elementary school system; student teachers intend to teach science subjects (i.e. biology, chemistry, physics, mathematics, home economics, technology, and computer science) in higher grades (i.e. Grades 5-9) of elementary school. The teachers' sample includes teachers from 20 different elementary schools across different Slovenian regions.

\section{Instruments}

The Values in Action Inventory of Strengths (VIA-IS; Peterson, Park, \& Seligman, 2004) is a self-assessment measure. It consists of 240 items, with each of 24 character strengths assessed by 10 items. The VIA-IS uses a 5-point Likert scale (from very much unlike me to very much like me). Sample items include "I love to learn new things" (love of learning) and "I always listen to people talk about their problems" (kindness). The administration time takes usually around 30 minutes. A potential range of strength scores is 10 through 50 for each of the 24 strengths, with higher scores indicating a greater endorsement of a specific strength. In general, scales show good reliability (Cronbach's alpha for all scales are $\alpha>0.70$ ), and stability (test-retest correlations over four months approach their internal consistencies $(r s \approx 0.70)$ (Park, Peterson, \& Seligman, 2006). In our samples, internal consistencies range from $\alpha=0.64$ (self-regulation in teachers' sample) to persistence ( $\alpha=0.86$ and $\alpha=0.87$ for teachers and students respectively).

The Satisfaction with Life Scale (SWLS; Diener, Emmons, Larsen, \& Griffin, 1985) is a five-item measure of satisfaction with life as a global cognitive judgement of one's own life. A sample item is "The conditions of my life are excellent". The measure uses a 7-point answer format (from strongly disagree to strongly agree). Responses are summed to yield an overall score of life satisfaction. SWLS is widely used in research and shows good psychometric properties across different studies (Diener, 1994). The scale was highly reliable in both our samples (teachers: $\alpha=0.84$, students: $\alpha=0.85$ ) 


\section{Procedure}

After obtaining the authors' permission, the VIA-IS was translated into the Slovenian language independently by two psychologists with a good knowledge of English. Translations were compared and discussed. Students filled in the pilot version of the questionnaire and gave feedback on the comprehensiveness of certain items. All items were then back translated to English by two professors of the English language.

The data was collected in a paper-pencil form. School headmasters and school psychologists were asked to distribute questionnaires to teachers. Questionnaires were anonymous and were returned via post. Students were asked by their teaching assistant to fill in the questionnaires. Both teachers and students could provide a code in order to receive feedback on their signature strengths.

\section{Results}

Mean scores, standard deviations and internal consistencies (Cronbach's alpha coefficients) were computed for each of the 24 VIA-IS scales. The means of all scales in both samples were compared. Finally, correlations with SWLS were calculated.

As shown in Table 1, the highest endorsed strengths were similar in both samples. These were fairness, kindness, honesty, and love. The lowest endorsed strengths in both samples were creativity, self-regulation, and spirituality. Moreover, teachers reported low endorsement of humour, while students' lowest endorsed strength was love of learning.

To compare the mean scores of VIA-IS scales between the samples, we used a Mann-Whitney $U$ test for scales with non-homogenous variances (these were: forgiveness, modesty, prudence, fairness, leadership, self-regulation, teamwork, curiosity, zest, hope, and perspective) and a t-test for the other scales with homogenous variances. The two samples differed significantly in the endorsement of most character strengths. The means of only seven VIA-IS scales did not differ significantly between the samples: kindness, love, teamwork, gratitude, hope, zest, and modesty. 
Table 1: Means and standard deviations of VIA-IS scales for both samples

\begin{tabular}{|c|c|c|c|}
\hline \multicolumn{4}{|c|}{ TEACHERS } \\
\hline Rank & VIA-IS scales & $M$ & $S D$ \\
\hline 1 & Fairness & 4.34 & 0.42 \\
\hline 2 & Honesty & 4.25 & 0.43 \\
\hline 3 & Kindness & 4.25 & 0.46 \\
\hline 4 & Curiosity & 4.17 & 0.46 \\
\hline 5 & Love & 4.15 & 0.46 \\
\hline 6 & Persistence & 4.11 & 0.47 \\
\hline 7 & Critical thinking & 4.06 & 0.45 \\
\hline 8 & Leadership & 4.05 & 0.47 \\
\hline 9 & Gratitude & 4.04 & 0.52 \\
\hline 10 & Teamwork & 4.04 & 0.44 \\
\hline 11 & Forgiveness & 4.03 & 0.44 \\
\hline 12 & $\begin{array}{l}\text { App. of beauty \& } \\
\text { excellence }\end{array}$ & 4.01 & 0.55 \\
\hline 13 & Prudence & 3.98 & 0.45 \\
\hline 14 & Hope & 3.95 & 0.49 \\
\hline 15 & Zest & 3.91 & 0.49 \\
\hline 16 & Perspective & 3.89 & 0.46 \\
\hline 17 & Love of learning & 3.89 & 0.57 \\
\hline 18 & Bravery & 3.87 & 0.46 \\
\hline 19 & Modesty & 3.84 & 0.50 \\
\hline 20 & Social intelligence & 3.83 & 0.46 \\
\hline 21 & Creativity & 3.83 & 0.49 \\
\hline 22 & Humour & 3.78 & 0.52 \\
\hline 23 & Self-regulation & 3.74 & 0.43 \\
\hline 24 & Spirituality & 3.69 & 0.69 \\
\hline
\end{tabular}

\begin{tabular}{|rlrr|}
\hline \multicolumn{4}{|c|}{ STUDENTS } \\
\hline Rank & VIA-IS scales & $\boldsymbol{M}$ & \multicolumn{1}{c|}{$\boldsymbol{S D}$} \\
\hline 1 & Kindness & 4.25 & 0.44 \\
2 & Love & 4.16 & 0.53 \\
3 & Fairness & 4.14 & 0.55 \\
4 & Honesty & 4.11 & 0.48 \\
5 & Teamwork & 3.93 & 0.55 \\
6 & Gratitude & 3.93 & 0.53 \\
7 & Humour & 3.93 & 0.58 \\
8 & Critical thinking & 3.92 & 0.58 \\
9 & Curiosity & 3.89 & 0.55 \\
10 & Leadership & 3.87 & 0.64 \\
11 & App. of beauty \& & 3.85 & 0.57 \\
12 & Hopcellence & 3.83 & 0.65 \\
13 & Zest & 3.83 & 0.60 \\
14 & Persistence & 3.75 & 0.63 \\
15 & Perspective & 3.74 & 0.52 \\
16 & Bravery & 3.71 & 0.59 \\
17 & Modesty & 3.70 & 0.62 \\
18 & Forgiveness & 3.66 & 0.64 \\
19 & Social intelligence & 3.63 & 0.54 \\
20 & Prudence & 3.62 & 0.59 \\
21 & Creativity & 3.56 & 0.65 \\
22 & Self-regulation & 3.39 & 0.68 \\
23 Spirituality & 3.35 & 0.80 \\
24 & Love of learning & 3.27 & 0.60 \\
\hline
\end{tabular}

There were no statistical differences between teachers' and students' scores on SWLS (Mann-Whitney U test: $Z=-1.55, p=0.12$ ). We calculated the correlations between VIA-IS scales and SWLS using Kendall's $\tau$ coefficient due to the non-homogeneity of variances in the two samples. 
Table 2: Correlations between VIA-IS scales and SWLS

\begin{tabular}{|c|c|c|}
\hline \multicolumn{3}{|c|}{ TEACHERS } \\
\hline Rank & VIA-IS scales & Kendall's $\tau$ \\
\hline 1 & Hope & $0.39^{* *}$ \\
\hline 2 & Zest & $0.30^{* *}$ \\
\hline 3 & Curiosity & $0.30^{* *}$ \\
\hline 4 & Gratitude & $0.29^{* *}$ \\
\hline 5 & Love & $0.29^{* *}$ \\
\hline 6 & Forgiveness & $0.23^{* *}$ \\
\hline 7 & Persistence & $0.22^{* *}$ \\
\hline 8 & Bravery & $0.21^{* *}$ \\
\hline 9 & Creativity & $0.21^{* *}$ \\
\hline 10 & Perspective & $0.19^{* *}$ \\
\hline 11 & Spirituality & $0.19^{* *}$ \\
\hline 12 & Honesty & $0.17^{* *}$ \\
\hline 13 & Social intelligence & $0.17^{* *}$ \\
\hline 14 & Critical thinking & $0.16^{* *}$ \\
\hline 15 & Love of learning & $0.15^{* *}$ \\
\hline 16 & Humour & $0.15^{* *}$ \\
\hline 17 & Kindness & $0.14^{*}$ \\
\hline 18 & Leadership & $0.14^{*}$ \\
\hline 19 & Self-regulation & $0.12^{*}$ \\
\hline 20 & Fairness & $0.12^{*}$ \\
\hline 21 & Prudence & 0.11 \\
\hline 22 & $\begin{array}{l}\text { App. of beauty \& } \\
\text { excellence }\end{array}$ & 0.10 \\
\hline 23 & Teamwork & 0.08 \\
\hline 24 & Modesty & 0.07 \\
\hline
\end{tabular}

\begin{tabular}{|rlr|}
\hline \multicolumn{3}{|c|}{ STUDENTS } \\
\hline Rank & VIA-IS scales & Kendall's $\tau$ \\
\hline 1 & Zest & $0.46^{* *}$ \\
2 & Love & $0.44^{* *}$ \\
3 & Hope & $0.43^{* *}$ \\
4 & Humour & $0.38^{* *}$ \\
5 & Curiosity & $0.36^{* *}$ \\
6 & Gratitude & $0.33^{* *}$ \\
7 & Persistence & $0.32^{* *}$ \\
8 & Teamwork & $0.31^{* *}$ \\
9 & Social intelligence & $0.30^{* *}$ \\
10 & Kindness & $0.29^{* *}$ \\
11 & Spirituality & $0.27^{* *}$ \\
12 & Bravery & $0.27^{* *}$ \\
13 & Leadership & $0.26^{* *}$ \\
14 & Perspective & $0.25^{* *}$ \\
15 & Self-regulation & $0.25^{* *}$ \\
16 & Forgiveness & $0.23^{* *}$ \\
17 & Creativity & $0.23^{* *}$ \\
18 & Honesty & $0.20^{*}$ \\
19 & Critical thinking & $0.19^{*}$ \\
20 & Prudence & $0.18^{*}$ \\
21 & Fairness & $0.16^{*}$ \\
22 & App. of beauty \& & 0.15 \\
23 & Love of learning & 0.15 \\
24 & Modesty & -0.03 \\
\hline
\end{tabular}

${ }^{* *} p<0.01,{ }^{*} p<0.05$

Table 2 shows that hope, zest, love, gratitude, and curiosity correlated the highest with SWLS in both samples. In the student sample, humour was also among the five highest correlations $(r=0.38)$. The lowest was the correlation of SWLS and modesty, which was even slightly negative in the student sample $(r=-0.03)$. Almost all correlations were statistically significant. 


\section{Discussion}

The first aim of the study was to explore the endorsement of the character strengths of teachers and student teachers. Since there is limited research on teachers' strengths, we wanted to determine which character strengths could be more frequently endorsed in people engaged in teaching professions.

We expected to find similar character strengths among in-service and preservice teachers. People who are drawn to teaching professions could share some specific personality traits, values, and virtue. Learning is the first aim of schools; therefore, teachers are expected to show high endorsement of the strengths associated with the virtues of wisdom and knowledge. For establishing and nurturing positive relationships, it is important for teachers to use their strengths of humanity. Moreover, the strengths of justice are important as well: teachers must function as role models of fair knowledge assessment and as mediators in different conflict situations. We expected to find higher rankings of knowledge strengths, humanity, and justice strengths in the samples of teachers and student teachers.

Our first presumption about the similarity of endorsed strengths of teachers and student teachers was confirmed: in both samples, the most and the least expressed strengths were similar. The highest endorsed strengths were fairness, kindness, honesty and love. The rank order slightly differed between the samples; e.g. the highest endorsed strength of the teachers was fairness and with the students' kindness. Kindness and love are categorized as strengths of humanity, while fairness and honesty are strengths of justice, as well as teamwork, at which both teachers and students scored high. The highest endorsed strengths in our samples were similar to general population samples (Park, Peterson, \& Seligman, 2006); however, mean scores were higher than the ones reported in previous studies, implying a possibility of higher endorsement of these strengths in people who are drawn to teaching professions.

The lowest endorsed strengths in both samples were creativity, selfregulation and spirituality. The low rank of creativity was our first unexpected finding. Teachers should be creative, in order to be able to foster the creativity of their students. Moreover, since there is a great accessibility of knowledge due to fast-developing information technology, teachers will have to be even more creative in order to engage their students in learning activities. Nevertheless, in-service teachers scored significantly higher at creativity than student teachers, which might reflect the fact that they must be creative in classrooms, while students might not use their creativity (enough) during their studies.

Our second unexpected finding was that teachers reported low endorsement of humour, although the mean score is still slightly higher than reported 
in general population samples (Linley et al., 2007; Park, Peterson, \& Seligman, 2006). Humour can be used appropriately in the classroom (Wanzer, Bainbridge Flymier, Wojtaszcsyk, \& Smith, 2010), and children love teachers who use humour. Research has shown improved perceptions of teachers who used humour in the classroom (Scott, 1976), enhanced the quality of the relationship between the students and these teachers (Welker, 1977), and led to higher teaching evaluations (Bryant, Comisky, \& Zillmann, 1980). However, the humour scale in VIA-IS represents only a part of a broad aspect of the sense of humour (Müller \& Ruch, 2011). It is intentionally restricted to forms of humour that "serve some moral good - by making the human condition more bearable /.../, by sustaining good cheer in the face of despair, by lubricating social interactions" (Peterson \& Seligman, 2004, p. 530). The scale is actually termed "humour and playfulness" and includes items regarding a great sense of humour, as well as items about cheering others up and sustaining good moods (e.g. Whenever my friends are in a gloomy mood, I try to tease them out of it.). Maybe teachers have different sense of humour and would score higher if other scales that measure humour were used (e.g. Sense of Humour Scale (SHS) or Humorous Behaviour Q-Sort Deck (HBQD) (Müller \& Ruch, 2011).

The last unexpected observation was that pre-service teachers scored low on love of learning, a strength that "teachers would like to see in their students, and that parents want to encourage in their children" (Peterson \& Seligman, 2004, p. 163). Love of learning is related to different constructs, including motivational orientation, competence, value and well-developed interest (Peterson \& Seligman, 2004). People having love of learning as strength are cognitively engaged and usually experience positive feelings when acquiring skills and knowledge (Krapp \& Fink, 1992; Peterson \& Seligman, 2004). Who then needs the love of learning more than teachers (or future teachers)? It seems that pre-service teachers perceive themselves to be in the role of students who must learn for their studies, being mainly extrinsically motivated with aim of passing the exams and finishing their studies. Perhaps they lack intrinsic motivation orientation and thus never or rarely learn for the sake of learning. To experience love of learning, people must "feel or expect to feel some sense of competence and efficacy in the learning process" (Peterson \& Seligman, 2004, p. 166). Hopefully, feelings of learning incompetence are not the case of student teachers from our sample, not only because they learn a lot about learning strategies during their studies, but also because they need to be competent regarding learning skills, in order to be able to teach pupils to acquire effective learning strategies.

It could be expected that people who perceive learning to be an important value possess love of learning among their higher strengths. Does it thus mean 
that the student teachers from our sample do not value learning? This being the case, interventions to stimulate learning as a value should be urgent. It would be necessary to form a context, in which learning as a value could be supported, including fostering positive relationships between faculty members and students on the one hand, and among students on the other hand, offering challenging tasks to students to support engagement and collaboration, and other interventions in order to meet the needs of students. For such an intervention intended to foster love of learning to be successful, faculty members must serve as good role models.

It might also be hypothesized that creative and eager-to-learn young people do not attend faculties of education (pedagogical faculties), which would be a cause of great concern. Educational faculties should emphasize the importance of learning as a value, and present creativity as one of the desired qualities of students, i.e. future teachers, when informing them about their study programs and inviting them to study at their faculties. Nevertheless, some character strengths may develop in time, as in research of Linley et al. (2007) love of learning showed a small but consistent effect of age.

Correlations between strengths and life satisfaction were as expected. The results from our samples of teachers and student teachers replicated previous research findings, which were obtained from general population samples. Hope, zest, gratitude, love, and curiosity correlated highest with life satisfaction and in students' sample also love and humour. Intellectual strengths usually correlate weakly with life satisfaction (Park, Peterson, \& Seligman, 2004; Peterson et al., 2007); however, the obtained correlations of creativity, critical thinking and love of learning were higher in our samples compared to previous research data, perhaps because of the importance of intellectual strengths for teachers.

Limitations of the present research should be acknowledged. Participants were teachers of higher grades of elementary schools; more representative samples could be used including teachers of lower grades of elementary school and high school teachers, in order to obtain more general strengths profile of teachers. The study could be expanded using different measures of life and work satisfaction, a measure of sense of humour, and a creativity test.

\section{Conclusions and implications}

Using the Values in Action Inventory of Strengths in the Slovenian language for the first time, in-service and pre-service teachers from our sample reported high endorsement of humanity and justice strengths and of some of the strengths of wisdom and knowledge. Strengths such as kindness, fairness, and critical thinking are substantial for a good teacher; thus teachers and future 
teachers should be stimulated to build upon these strengths. In contrast, surprisingly, love of learning scored lowest of students' strengths, and creativity ranked low in both samples. It seems imperative to work more systematically on students' intellectual strengths during their undergraduate studies, so they could perceive learning as an important value and become good role models for their students in the future. Additionally, undergraduate study programmes for teacher education should offer numerous possibilities for students to express and foster their creativity.

\section{References}

Brdar, I., \& Kashdan, T. B. (2010). Character strengths and well-being in Croatia: An empirical investigation of structure and correlates. Journal of Research in Personality, 40(1), 151-154. Bryant, J., Comisky, P. W., Crane, J. S., \& Zillman, D. (1980). Relationship between college teachers' use of humor in the classroom and students' evaluations of their teachers. Journal of Educational Psychology, 72, 511-519.

Chan, D. W. (2009). The hierarchy of strengths: Their relationships with subjective well-being among Chinese teachers in Hong Kong. Teaching and Teacher Education, 25(6), 867-875.

Diener, E. (1994). Assessing subjective well-being: Progress and opportunities. Social Indicators Research, 31, 103-157.

Diener, E., Emmons, R. A., Larsen, R. J., \& Griffin, S. (1985). The Satisfaction with Life Scale. Journal of Personality Assessment, 49, 71-75.

Krapp, A., \& Fink, B. (1992). The development and function of interests during the critical transition from home to preschool. In K. A. Renninger, S. Hidi, \& A. Krapp (Eds.), The Role of Interest in Learning and Development (pp.397-429). Hillsdale, NJ: Erlbaum.

Linley, P. A., Maltby, J., Wood, A. M., Joseph, S., Harrington, S., Peterson, C., Park, N., \& Seligman, M. E. P. (2007). Character strengths in the United Kingdom: The VIA Inventory of Strengths.

Personality and Individual Differences, 43, 341-351.

Müller, L., \& Ruch, W. (2011). Humor and strengths of character. Journal of Positive Psychology, 6(5), $368-376$.

Park, N., Peterson, C., \& Seligman, M. E. P. (2004). Strengths of character and well-being. Journal of Social and Clinical Psychology, 23(5), 603-619.

Park, N., Peterson, C., \& Seligman M. E. P. (2006). Character strengths in fifty-four nations and the fifty US states. Journal of Positive Psychology, 1(3), 118-129.

Peterson, C., \& Park, N. (2006). Character strengths in organizations. Journal of Organizational

Behavior, 27, 1149-1154

Peterson, C., Park, N., \& Seligman, M. E. P. (2004). Assessment of character strengths. In G. P. Koocher, J. C. Norcross, \& S. S. Hill, III (Eds.), Psychologists' Desk Reference (2 ${ }^{\text {nd }}$ ed.). New York: Oxford University Press. 
Peterson, C., Ruch, W., Beermann, U., Park, N., \& Seligman, M. E. P. (2007). Strengths of character, orientations to happiness, and life satisfaction. Journal of Positive Psychology, 2(3), 149-156.

Peterson, C., \& Seligman, M. E. P. (2004). Character Strengths and Virtues: A handbook and classification. New York: Oxford University Press.

Ruch, W., Proyer, R. T., Harzer, C., Park, N., Peterson, C., \& Seligman, M. E. P. (2010). Values in Action Inventory of Strengths (VIA-IS): Adaptation and validation of the German version and the development of a peer-rating form. Journal of Individual Difference, 31(3), 138-149.

Seligman, M. E. P., \& Cziksentmihalyi, M. (200o). Positive psychology: An introduction. American Psychologist, 55, 5-14.

Seligman, M. E. P., Steen, T. A., Park, N. \& Peterson, C. (2005). Positive Psychology Progress: Empirical Validation of Interventions. American Psychologist, 6o(5) 410-421.

Wanzer, M. B., Bainbridge Frymier, A., Wojtaszczyk, A. M., Smith, T. (2006). Appropriate and inappropriate uses of humor by teachers. Communication Education, 55(2), 178-196.

Scott, T. M. (1976). Humor in teaching. Journal of Physical Education and Recreation, 7, 18.

Welker, W. A. (1977). Humor in education: A foundation for wholesome living. College Student Journal, 11, 252-254.

\section{Biographical note}

Polona GradišeK works as a teaching assistant for educational psychology at the Faculty of Education, University of Ljubljana. She is a Ph.D. student of psychology at the Faculty of Arts, University of Ljubljana. Her areas of research are educational and positive psychology. 